\title{
ANALISIS FAKTOR-FAKTOR YANG MEMPENGARUHI STRESS KERJA PADA TENAGA KEBERSIHAN KOTA DI DINAS LINGKUNGAN HIDUP KABUPATEN GIANYAR TAHUN 2017
}

\author{
Kadek Dery Suryawan \\ Prodi Pendidikan Ekonomi, Fakultas Ekonomi \\ Universitas Pendidikan Ganesha Singaraja, \\ Indonesia \\ e-mail: kadeksuryawan412@gmail.com
}

\begin{abstract}
Abstrak
Penelitian ini bertujuan untuk mengetahui faktor-faktor yang mempengaruhi stress kerja dan faktor yang paling dominan mempengaruhi stress kerja pada tenaga kebersihan kota di Dinas Lingkungan Hidup Kabupaten Gianyar Tahun 2017. Penelitian ini merupakan jenis penelitian kuantitatif dengan pendekatan faktorial. Data dikumpulkan dengan menggunakan kuesioner kemudian diolah dengan tehnik analisis faktor menggunakan program spss 16 for windows. Hasil penelitian ini menunjukkan bahwa terdapat empat faktor yang mempengaruhi stress kerja pada tenaga kebersihan kota yakni tuntutan antar personal dengan nilai eigenvalue sebesar 6,492, tuntutan tugas dengan nilai eigenvalue 5,589, tuntutan fisik dengan nilai eigenvalue sebesar 1,747 dan tuntutan fisik dengan nilai eigenvalue sebesar 1,114. Dari keempat faktor tersebut, faktor yang paling dominan mempengaruhi stress kerja pada tenaga kebersihan kota adalah faktor tuntutan antar personal dengan nilai eigenvalue terbesar yaitu 6,492. Khususnya mengenai rendahnya dukungan dari pimpinan dengan nilai loading factor terbesar di dalam faktor tuntutan antar personal yaitu 0,987 .
\end{abstract}

Kata kunci : Stress kerja, tenaga kebersihan

\section{Abstract}

This research aims to determine the factors that affect work stress and the most dominant factor affecting the work stress on city cleaning personel in the Environment Office of Gianyar Regency in 2017. This research is a type of quantitative research with a factorial approach. Data was collected by using questioner then processed by factor analysis technique using SPSS 16 for windows program. The result of this research shows that there are four factors that influence the work stress on city cleaning personnel the interpersonal demands with the eigenvalue of 6.492, the task demands with eigenvalue 5,589, physical demands with eigenvalue of 1.747 and physical demands with eigenvalue of 1.114 . Of the four factors, the most dominant factor affecting work stress on city cleaning personnel is the factor of interpersonal demands with the largest eigenvalue is 6.492. Especially regarding the low support from the leader with the largest loading factor in the interpersonal demand factor is 0.987 .

Keywords: Work stress, city cleaning personnel

\section{PENDAHULUAN}

Stress merupakan kata yang sering kali diucapkan oleh orang-orang dalam aktivitas kehidupannya ketika orang tersebut mengalami suatu ketegangan atau menghadapi suatu masalah. Irham Fahmi (2013) mendefinisikan bahwa stress adalah suatu keadaan yang menekan diri dan jiwa seseorang di luar batas kemampuannya, sehingga jika terus dibiarkan tanpa ada solusi maka ini akan berdampak pada kesehatannya. Stress tidak timbul begitu saja namun sebabsebab stress timbul umumnya diikuti oleh faktor peristiwa yang mempengaruhi kejiwaan seseorang, dan peristiwa itu terjadi di luar dari kemampuannya sehingga kondisi tersebut telah menekan jiwanya.

Gregory Moonhead \& Ricky W. Griffin (2013) menyatakan bahwa stress 
sebagai respons adaptif seseorang terhadap rangsangan yang menempatkan tuntutan psikologis atau fisik secara berlebihan kepada dirinya. Sedangkan Robbins (2006) mendefinisikan bahwa stress adalah kondisi dinamik yang di dalamnya individu menghadapi peluang, kendala (constraits) atau tuntutan (demand) yang terkait dengan apa yang sangat diinginkan dan yang di hasilkan persepsi sebagai tidak pasti tapi penting. Gregory Moonhead dan Ricky W. Griffin (2013) menyatakan ada 2 bentuk dari stress dimana yang pertama disebut dengan Distress. Distress merupakan stress pada individu yang menghasilkan konsekuensi-konsekuensi negatif. Sedangkan eustress merupakan stress pada individu yang menghasilkan konsekuensi positif.

Pines dan Aronson menyatakan stress kerja yang terjadi dalam jangka yang cukup lama dan berlangsung dalam intensitas yang tinggi mengakibatkan individu akan mengalami kelelahan fisik maupun mental. Kondisi ini disebut dengan "burn out", yang merupakan salah satu bentuk stress yang tampak pada sikap perilaku individu. Burnout merupakan kondisi emosional dimana seseorang merasa lelah dan jenuh secara mental ataupun fisik sebagai akibat tuntutan pekerjaan yang meningkat.

Menurut Caputo (1991) kelelahan emosional ditandai dengan terkurasnya sumber-sumber emosional, yakni perasaan frustasi, putus asa, sedih, tidak berdaya, tertekan, apatis terhadap pekerjaan dan merasa terbelenggu oleh pekerjaan sehingga seseorang merasa tidak mampu memberikan pelayanan secara psikologis. Selain itu, mereka mudah tersinggung dan mudah marah tanpa alasan yang jelas. Melihat gejala yang ditimbulkan dari stress kerja tersebut tentu hal ini dapat dipengaruhi oleh beberapa faktor, menurut Gregory Moonhead \& Ricky W. Griffin (2013) stressor organisasi (organizational stressor) adalah berbagai faktor di tempat kerja yang dapat mempengaruhi stress. Empat faktor tersebut antara lain tuntutan tugas, tuntutan fisik, tuntutan peran serta tuntutan antar personal.
Faktor pertama yang mempengaruhi stress kerja menurut Gregory Moonhead dan Ricky W. Griffin (2013) adalah tuntutan tugas (task demands).Tuntutan tugas berkaitan dengan tugas spesifik yang dilakukan oleh seseorang. Jenis pekerjaan mempunyai sifat lebih menimbulkan stress daripada yang lainnya. Pekerjaan dokter ahli bedah, pengatur lalu lintas udara, dan pelatih sepakbola professional secara umum lebih menimbulkan stress dibandingkan dengan para praktisi umum, agen tiket pesawat terbang dan manajer perlengkapan tim sepak bola. Jadi jenis pekerjaan memiliki pengaruhnya masingmasing terhadap stress yang dialami oleh pekerja tersebut.

Di luar tekanan-tekanan terkait tugas spesifik, aspek lain dari pekerjaan dapat menghadirkan ancaman fisik pada kesehatan sesorang. Kondisi tidak sehat terdapat dalam pekerjaan seperti penambangan batu bara dan penanganan limbah-limbah beracun. Keamanan adalah tuntutan tugas lainnya yang dapat menimbulkan stress. Seseorang dalam pekerjaan yang relative aman kemungkinan tidak akan terlalu khawatir akan kehilangan posisi tersebut. Ancaman terhadap keamanan pekerjaan dapat meningkatkan stress. Sebagai contoh, stress biasanya meningkat diseluruh organisasi selama periode pemecatan atau segera setelah merger dengan perusahaan lain. Stressor tuntutan tugas yang terakhir adalah kelebihan beban. Kelebihan beban terjadi ketika seseorang memiliki lebih banyak pekerjaan dari yang dapat ia tangani. Kelebihan beban dapat bersifat kuantitatif (orang tersebut mempunyai terlalu banyak tugas untuk dilakukan atau terlalu sedikit waktu untuk melakukannya) dan kualitatif (orang tersebut mungkin meyakini bahwa ia kurang mempunyai kemampuan untuk melakukan pekerjaan tersebut). Tuntutan tugas rendah dapat menyebabkan kebosanan seperti kelebihan beban dapat menyebabkan ketegangan dan kegelisahan.

Faktor kedua yang mempengaruhi stress kerja menurut Gregory Moonhead dan Ricky W. Griffin (2013) adalah 
Tuntutan fisik (physical demands). Tuntutan fisik dari sebuah pekerjaan adalah prasyarat fisik pada pekerjaannya. Tuntutan seperti ini merupakan fungsi dari karakteristik fisik dari situasi dan tugas fisik yang dibutuhkan dalam pekerjaan. Salah satu elemen yang penting adalah temperatur. Bekerja di luar ruangan dengan temperatur yang ekstrem dapat menyebabkan stress, demikian juga bekerja di dalam kantor yang tidak dipanaskan atau didinginkan dapat menyebabkan stress pada pegawai. Desain kantor juga dapat menjadi masalah. Kantor yang didesain dengan buruk dapat mempersulit pegawai untuk memiliki privasi atau menyebabkan terlalu banyak atau terlalu sedikit interaksi sosial. Terlalu banyak interaksi sosial dapat mengganggu seseorang dari tugasnya. Sedangkan terlalu sedikit interaksi dapat menimbulkan kebosanan atau kesepian. Demikian juga pencahayaan yang buruk, permukaan kerja yang tidak memadai dapat menimbulkan stress. Lebih lanjut, pekerjaan shift dapat menimbulkan gangguan bagi orang-orang karena caranya mempengaruhi tidur dan aktivitas waktu senggang mereka.

Faktor ketiga yang mempengaruhi stress kerja menurut Gregory Moonhead dan Ricky W. Griffin (2013) tuntutan peran (role demands). Tuntutan peran juga dapat menimbulkan stress kepada orangorang dalam organisasi. Sebuah peran (role) adalah serangkaian perilaku yang diharapkan sehubungan dengan posisi tertentu dalam sebuah kelompok atau organisasi. Individu merasakan ekspektasi peran dengan derajat akurasi yang beragam kemudian berusaha untuk mewujudkan peran tersebut. Namun, "kesalahan" dapat muncul dalam proses ini, menghasilkan masalah yang memicu stress yang disebut dengan ambiguitas peran. Ambiguitas peran (role ambiguity) muncul ketika suatu peran tidak jelas. Jika instruktur kita memerintahkan kita menulis sebuah makalah akhir, tetapi menolak untuk memberikan informasi lebih, kita mungkin akan mengalami ambiguitas. Dalam situasi kerja, ambiguitas peran dapat disebabkan oleh deskripsi kerja yang buruk, instruksi pengawas yang samar-samar, atau petunjuk yang tidak jelas dari rekan kerja.

Faktor keempat yang mempengaruhi stress kerja menurut Gregory Moonhead dan Ricky W. Griffin (2013) adalah tuntutan antar personal. Terdapat tiga bentuk tuntuan antar personal yaitu tekanan kelompok, gaya kepemimpinan, dan konflik antarpersonal. Tekanan Kelompok dapat meliputi tekanan untuk membatasi hasil, tekanan untuk mematuhi norma kelompok dan sebagainya. Gaya kepemimpinan dapat menyebabkan stress, misalnya seorang karyawan membutuhkan dukungan sosial yang besar dari pemimpinnya. Namun pemimpin tersebut cukup kasar dan tidak menunjukan rasa kasihan kepadanya. Karyawan ini mungkin akan merasakan stress. Kepribadian dan perilaku yang berkonflik dapat menyebabkan stress. Konflik dapat terjadi ketika dua orang atau lebih harus bekerja bersama meskipun kepribadian, sikap, dan perilaku mereka berbeda.

Kabupaten Gianyar merupakan salah satu kabupaten yang memiliki seni dan budaya yang beragam.Hal ini menjadikan Kabupaten Gianyar sebagai salah satu destinasi wisata yang ramai dikunjungi oleh wisatawan baik domestik maupun mancanegara. Sebagai salah satu daerah tujuan wisatawan maka banyak hal yang perlu diperhatikan salah satunya adalah kebersihan kota. Lingkungan kota yang bersih akan memberikan kenyamanan baik bagi warga lokal maupun turis yang berlibur. Salah satu dinas di Pemeritahan Kabupaten Gianyar yang bertanggung jawab atas kebersihan kota adalah Dinas Lingkungan Hidup.

Dinas Lingkungan Hidup dibentuk berdasarkan Peraturan Daerah Kabupaten Gianyar Nomor 5 Tahun 2016 tanggal 18 November 2016. Tugas dan Fungsi Dinas Lingkungan Hidup Kabupaten Gianyar berdasarkan Peraturan Bupati Nomor 74 Tahun 2016 Tanggal 14 Desember 2016 adalah membantu pemerintah kabupaten Gianyar dalam melaksanakan tugas dibidang penataan lingkungan hidup, penanganan persampahan, pengendalian pencemaran 
dibidang lingkungan hidup, penaatan, penerima pengaduan dan pelanggaranpelanggaran dibidang lingkungan hidup.

Bidang yang bertanggung jawab dalam menangani persampahan dan kebersihan kota adalah bidang persampahan. Tugas pokok dan fungsi dari bidang persampahan adalah melaksanakan pembinaan kepada masyarakat tentang pentingnya memelihara kebersihan lingkungan, tugas penyapuan, pengumpulan sampah di lingkungan masyarakat, pengumpulan sampah di tempat pembuangan sementara (TPS), pengangkutan sampah dari tempat pembuangan sementara (TPS) ke tempat pembuangan akhir (TPA). Setelah penulis melakukan observasi dan wawancara kepada pimpinan beserta masing-masing kepala seksi yang berada di Dinas Lingkungan Hidup Kabupaten Gianyar bahwa dalam pelaksanaan penaganan sampah, volume sampah yang dihasil kan setiap hari yang ada di kota Gianyar, dalam 1 hari menghasilkan sampah sebanyak 185 $\mathrm{m} /$ kubik setiap hari dimana sampah tersebut meliputi sampah rumah tangga, sampah pasar dan sampah tempat umum lainnya. Jumlah sampah ini akan meningkat drastis saat hari raya maupun saat diselenggarakannya event-event di Kota Gianyar. Armada yang dioperasionalkan untuk penanganan sampah tersebut meliputi 13 truck, 33 kendaaran viar, 9 dam truck dan 3 amrol. Khusus di kota Gianyar Dinas Lingkungan Hidup memiliki tenaga kebersihan kota sebanyak 94 orang yang bertugas untuk melakukan penyapuan dan pengumpulan sampah ke masing-masing TPS di kota Gianyar yang kemudian diangkut petugas truck ke TPA.

Dari keadaan sampah di Kota Gianyar baik yang bersumber dari sampah yang ada di Jalan, sampah rumah tangga, sampah pasar dan sumber sampah di tempat umum lainnya, maka dapat dibayangkan bagaimana beban kerja daripada tenaga kebersihan kota yang cukup tinggi. Tentu dalam menangani permasalahan sampah ini akan berdampak pada stress kerja tenaga kebersihan kota melihat tuntutan kerja yang dihadapi setiap harinya. Selain itu dalam melaksanakan tugas nya, tenaga kebersihan kota memiliki jam operasional dari jam 05.00 wita sampai selesai dan dari jam 15.00 wita sampai selesai. Tuntutan fisik dari tenaga kebersihan kota juga berdampak pada stress kerja yang dialaminya, melihat keadaan cuaca yang tidak menentu dan keadaan lokasi sampah yang dapat menyebabkan gangguan kesehatan terhadap tenaga kebersihan kota. Stress kerja ini ditunjukan dengan munculnya gejala stress kerja seperti tidak sabar dalam menjalani pekerjaannya, lekas marah, sensitive dan mudah tersinggung, konsentrasi kurang dalam bekerja, muncul nya efek organisatoris atau kelembagaan yaitu sering absen dalam kerja dengan berbagai alasan, menghindari tanggung jawab, dan produktivitas menurun. Turunnya produktivitas ini terlihat dengan gagalnya Kabupaten Gianyar memperoleh Adipura dari tahun 2014.

Tujuan penelitian ini adalah untuk mengetahui faktor-faktor yang mempengaruhi stress kerja pada tenaga kebersihan kota di Dinas Lingkungan Hidup Kabupaten Gianyar Tahun 2017 dan untuk mengetahui faktor apa yang dominan mempengaruhi stress kerja pada tenaga kebersihan kota di Dinas Lingkungan Hidup Kabupaten Gianyar Tahun 2017.

\section{METODE}

Jenis penelitian yang digunakan dalam penelitian ini adalah penelitian kuantitatif dengan pendekatan faktorial. Tujuan dalam penelitian ini adalah untuk mencari hubungan interdependensi antar variabel agar dapat menggambarkan faktor-faktor yang mempengaruhi stress kerja pada tenaga kebersihan kota di Dinas Lingkungan Hidup Kabupaten Gianyar Tahun 2017 dan untuk mengatahui faktor yang paling dominan mempengaruhi stress kerja pada tenaga kebersihan kota di Dinas Lingkungan Hidup Kabupaten Gianyar Tahun 2017. Pengumpulan data dilakukan dengan menggunakan kuesioner, kemudian diolah atau dianalisis dengan menggunakan analisis factor. Populasi di dalam 
penelitian ini adalah seluruh tenaga kebersihan kota di Dinas Lingkungan Hidup dengan data yang diperoleh dari observasi. Jumlah populasi dalam penelitian ini sebanyak 94 orang. Menurut Arikunto (2010), apabila objek atau populasi kurang dari 100, maka sebaiknya semua dijadikan sebagai sasaran penelitian. Oleh karena itu, penelitian ini merupakan penelitian populasi atau penelitian sampel jenuh yang artinya semua populasi dijadikan sebagai sasaran penelitian.

Jenis data yang digunakan dalam penelitian ini yaitu data kuantitatif dan data kualitatif. Ditinjau dari sumbernya, data yang digunakan dalam penelitian ini adalah data primer dan data skunder.

Teknik pengumpulan data yang dilakukan dalam penelitian ini adalah menggunakan kuesioner. Kuesioner ini menggunakan skala likert. Skala likert digunakan karena skala likert merupakan metode pengukuran yang digunakan untuk mengukur sikap,pendapat dan persepsi seseorang tentang fenomena sosial (Sugiyono, 2007). Dalam melakukan penelitian terhadap variabel-variabel yang akan diuji, pada setiap jawaban akan diberi skor atau bobot. Kuesioner sebagai instrument pengumpulan data ordinal yang merupakan penjabaran dari indikator, sebelum digunakan untuk mengumpulkan data di lapangan, terlebih dahulu harus diuji tingkat validitas dan reliabilitasnya.

Instrumen penelitian ini adalah kuesioner yang disebarkan kepada responden yaitu tenaga kebersihan kota di Dinas Lingkungan Hidup Kabupaten Gianyar. Kuesioner sebagai instrument pengumpulan data ordinal yang merupakan penjabaran dari indikator, sebelum digunakan untuk mengumpulkan data di lapangan, terlebih dahulu harus diuji tingkat validitas dan reliabilitasnya. Sesuai dengan rumusan masalah, tujuan penelitian dan juga jenis data yang dikumpulkan, maka metode analisis data yang digunakan dalam penelitian ini adalah model analisis faktor. Data yang didapat dari kuesioner masih berupa data ordinal, sedangkan analisis data yang dipakai untuk membuktikan kebenaran pengujian analisis faktor mengisyaratkan minimal data interval, maka data ordinal tersebut perlu ditingkatkan skala pengukurannya menjadi skala interval melalui "Method of Succestive Interval.

\section{HASIL DAN PEMBAHASAN \\ Hasil}

Analisis Faktor merupakan analisis statistik yang bertujuan untuk mengidentifikasi, mengelompokan, dan meringkas faktor-faktor yang merupakan dimensi suatu variabel. Dalam penelitian ini digunakan teknik analisis faktor dengan bantuan aplikasi Statistical Package for Social Science (SPSS) 16.0 for Windows. Analisis faktor meliputi tahap-tahap sebagai berikut. Tahap pertama Matrik Korelasi dapat dilihat pada output analisis faktor yaitu pada tabel koefisien correlation matrix. Dari matrix korelasi ini didapat beberapa pengujian yang merupakan persyaratan awal agar analisis faktor dapat dilakukan yaitu:Nilai uji determinant of correlation. Analisis faktor mensyaratkan bahwa variabel yang diidentifikasikan harus saling berhubungan yang ditunjukkan dengan nilai determinant of correlation yang mendekati nol. Hasil analisis faktor pada penelitian ini menunjukkan nilai determinant of correlation yang mendekati nol yaitu sebesar $6,36.10^{-12}$ Dengan nilai yang mendekati nol berarti bahwa variabel-variabel yang diidentifikasikan saling berhubungan, Nilai Uji KaiserMeyer-Olkin (KMO). Nilai uji KMO yang digunakan untuk menguji derajat interkorelasi antara variabel dan ketepatan pemakaian analisis faktor. Analisis faktor mensyaratkan nilai $\mathrm{KMO}$ minimum 0,50. Hasil analisis faktor dalam penelitian ini menunjukkan nilai $\mathrm{KMO}$ sebesar 0,841 melewati batas minimum 0,50 . Hal ini berarti bahwa variabel ada hubungan satu sama lain sehingga analisis faktor tepat digunakan dalam penelitian ini. Hasil uji Barlett's Test of Sphericity menunjukan hasil yang signifikan pada 0,000. Hal ini berarti matrik korelasi memiliki korelasi yang signifikan dengan sejumlah variabel, karena dilihat dari nilai signifikan lebih 
p-ISSN : 2599-1418

e-ISSN : 2599-1426

kecil dari 0,05 dan Nilai uji Measure of Sampling Adequency (MSA) yang digunakan untuk mengetahui kecukupan sampel dimana analisis faktor mensyaratkan nilai MSA > 0,50. Hal ini dapat dilihat pada angka yang membentuk
Jurnal Pendidikan Ekonomi Undiksha

Volume 10 No. 1 Tahun 2018

tanda "a" pada Anti-image Matrices. Untuk masing-masing variabel dapat dilihat pada Tabel 1. Dimana tabel 1 menerangkan nilai MSA setiap variabel yang memiliki nilai diatas 0,50 .

Tabel 1. Nilai MSA untuk Masing-Masing Variabel

\begin{tabular}{cll}
\hline Variabel & Nilai MSA & Keputusan \\
\hline 1 & $0,792>0,50$ & Dapat digunakan untuk analisis faktor \\
2 & $0,755>0,50$ & Dapat digunakan untuk analisis faktor \\
3 & $0,887>0,50$ & Dapat digunakan untuk analisis faktor \\
4 & $0,721>0,50$ & Dapat digunakan untuk analisis faktor \\
5 & $0,748>0,50$ & Dapat digunakan untuk analisis faktor \\
6 & $0,892>0,50$ & Dapat digunakan untuk analisis faktor \\
7 & $0,718>0,50$ & Dapat digunakan untuk analisis faktor \\
8 & $0,888>0,50$ & Dapat digunakan untuk analisis faktor \\
9 & $0,862>0,50$ & Dapat digunakan untuk analisis faktor \\
10 & $0,767>0,50$ & Dapat digunakan untuk analisis faktor \\
11 & $0,673>0,50$ & Dapat digunakan untuk analisis faktor \\
12 & $0,830>0,50$ & Dapat digunakan untuk analisis faktor \\
13 & $0,929>0,50$ & Dapat digunakan untuk analisis faktor \\
14 & $0,900>0,50$ & Dapat digunakan untuk analisis faktor \\
15 & $0,917>0,50$ & Dapat digunakan untuk analisis faktor \\
16 & $0,869>0,50$ & Dapat digunakan untuk analisis faktor \\
17 & $0,946>0,50$ & Dapat digunakan untuk analisis faktor \\
18 & $0,890>0,50$ & Dapat digunakan untuk analisis faktor \\
\hline
\end{tabular}

Pada tabel 8 terdapat nilai MSA untuk masing-masing variabel. Setelah di uji Measures of Sampling Adequancy (MSA) dari ke-18 variabel tersebut tidak ada variabel yang dikeluarkan dari model Data hasil tabel diatas mendapatkan 18 variabel yang sesuai dengan kriteria yang ditentukan yaitu nilai MSA > 0,5 sehingga langkah analisis faktor dapat dilanjutkan.

Tahap kedua Penentuan jumlah faktor masing-masing merupakan gabungan dari beberapa variabel yang saling berkorelasi yang didasarkan atas eigenvalue. Eigenvalue merupakan penjumlahan variance nilai-nilai korelasi setiap faktor terhadap masing-masing variabel yang membentuk faktor bersangkutan.

Semakin besar eigenvalue suatu faktor, maka semakin representatif faktor tersebut sebagai wakil dari kelompok variabel. Nilai eigenvalue dapat dilihat pada tabel Total Variance Explained. Faktor yang dipilih untuk analisis lebih lanjut dalam suatu model didasarkan pada batasan faktor yang memiliki eigenvalue > 1 , berdasarkan hal tersebut maka terdapat 4 (empat) faktor mempengaruhi stres kerja pada tenaga kebersihan kota di Dinas Lingkungan Hidup Kabupaten Gianyar Tahun 2017. Nilai eigenvalue dapat dilihat pada tabel 2.

Tahap ketiga rotasi faktor, untuk mempermudah interpretasi pengelompokan variabel ke dalam setiap faktor maka dilakukan rotasi faktor. Metode yang digunakan untuk merotasi faktor pada penelitian ini adalah metode varimax yaitu metode yang bertujuan untuk merotasi faktor awal hasil ekstrasi yang akan menghilangkan matrik yang lebih sederhana untuk mempermudah interpretasi dengan meminimalkan variabel yang memiliki loading yang tinggi terhadap faktornya.

Matrik faktor setelah dirotasi ini dapat dilihat pada output yaitu pada tabel rotated component matrix. Dimana hasil rotasi ini dapat dilihat secara rinci pada tabel 2. 
Tabel 2. Hasil Rotasi Faktor Teknik Varimax dengan Loading Factor $>0,5$

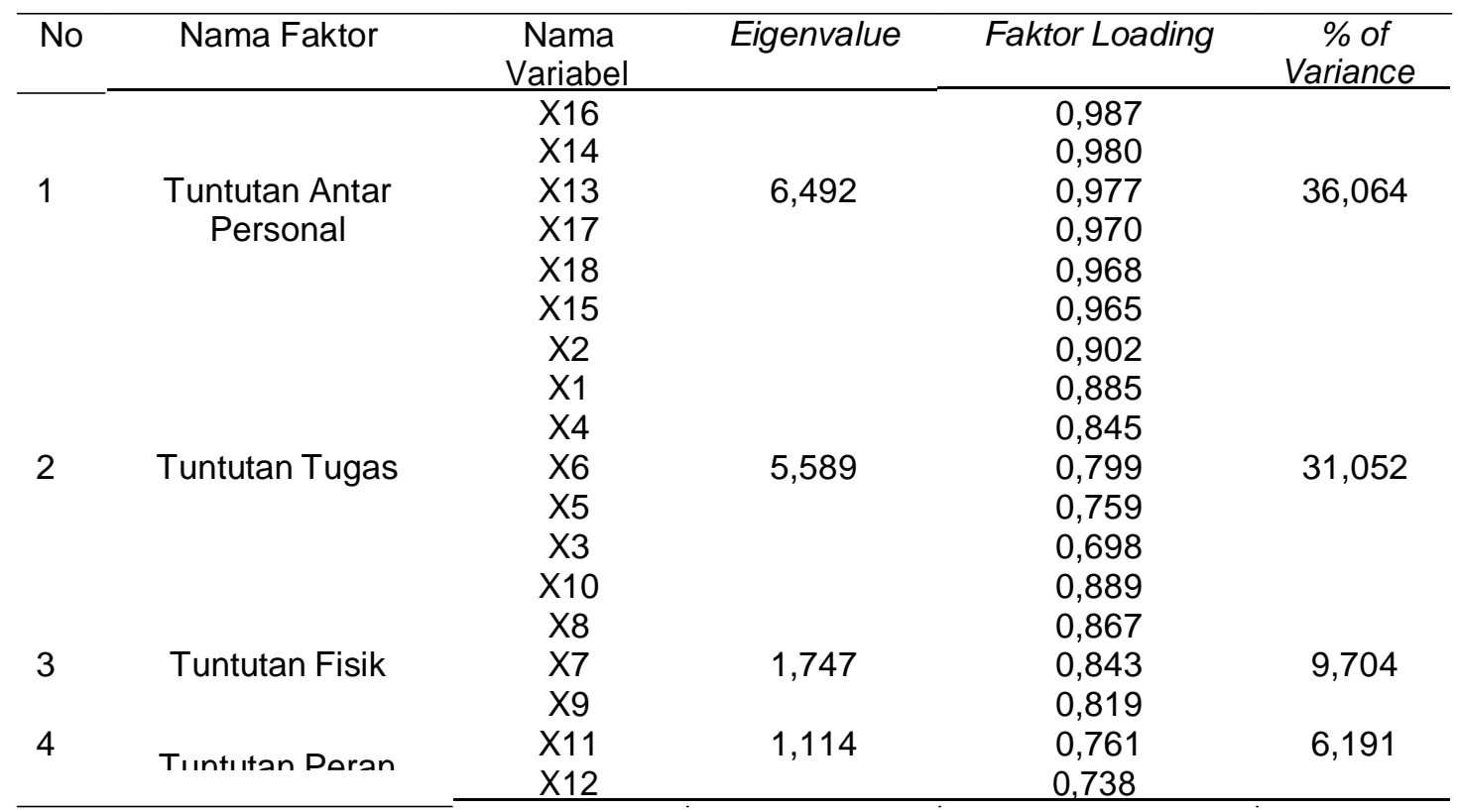

Pada tabel 10 jelas menunjukkan bahwa ada 18 variabel yang mempunyai loading factor $>0,50$, sehingga terkelompokkan menjadi 4 (empat) faktor. Ini berarti faktor-faktor yang mempengaruhi stres kerja pada tenaga kerja kebersihan kota di Dinas Lingkungan Hidup Kabupaten Gianyar Tahun 2017 dapat dijelaskan oleh 4 faktor tersebut. Masing-masing faktor diberi nama sebagai berikut: faktor 1 dinamakan faktor tuntutan antar personal, faktor 2 dinamakan faktor tuntutan tugas, faktor 3 dinamakan faktor tuntutan fisik, dan faktor 4 dinamakan faktor tuntutan peran.

Tahap ke empat Interpretasi faktor dilakukan dengan mengelompokkan variabel-variabel yang mempunyai loading factor (korelasi) minimal 0,5, semakin tinggi loading factor berarti semakin erat hubungan antara variabel dengan faktor tersebut. Sujarweni Wiratna (2016) menyarankan bahwa "Nilai loading factor hendaknya tidak kurang dari 0,5 , sehingga 18 (delapan belas) variabel yang membentuk empat faktor dapat digunakan untuk analisis selanjutnya. Adapun penjelasan dari masing-masing faktor serta variabel yang dominan mempengaruhi stres kerja pada tenaga kebersihan kota di Dinas Lingkungan
Hidup Kabupaten Gianyar Tahun 2017 secara rinci dijelaskan sebagai berikut. faktor tuntutan antar personal memiliki eigenvalue sebesar 6,492 dan dengan nilai persentase variance yang mempengaruhi stres kerja pada tenaga kebersihan kota di Dinas Lingkungan Hidup Kabupaten Gianyar Tahun 2017 sebesar 36,064\%. Faktor ini dibentuk oleh variabel-variabel sebagai berikut. Kurang dukungan dari pimpinan (X16) dengan loading factor sebesar 0,987 , tertekan dengan target hasil yang ditetapkan (X14) dengan loading factor sebesar 0,980, tidak nyaman dengan aturan kelompok (X13) dengan loading factor sebesar 0,977, kurang baiknya hubungan dengan teman sekerja (X17) dengan loading factor sebesar 0,970, Kurang dukungan dari rekan kerja (X18) dengan loading factor sebesar 0,968 dan harapan pimpinan (X15) dengan loading factor sebesar 0,965Berdasarkan besarnya loading factor variabel variabel tersebut diatas, ternyata variabel kurangnya dukungan dari pemimpin (X16) memiliki pengaruh yang dominan di dalam faktor tuntutan antar personal (faktor I) sedangkan variabel harapan pimpinan (X17) memiliki pengaruh yang paling kecil di dalam faktor tuntutan antar personal (faktor 1).Faktor 
tuntutan fisik memiliki eigenvalue sebesar 5,589 dan dengan nilai persentase variance yang mempengaruhi stres kerja pada tenaga kebersihan kota di Dinas Lingkungan Hidup Kabupaten Gianyar Tahun 2017 sebesar 31,052\%. Faktor ini dibentuk oleh variabel-variabel sebagai berikut. Suka dengan pekerjaan (X2) dengan loading factor sebesar 0,902, Pekerjaan yang dilakukan mudah untuk dikerjakan (X1) dengan loading factor sebesar 0,885 , rotasi penempatan lokasi kerja yang berubah-ubah (X4) dengan loading factor sebesar 0,845, tidak cukup waktu menyelesaikan pekerjaan (X6) dengan loading factor sebesar 0,799, banyaknya pekerjaan (X5) dengan loading factor sebesar 0,759 dan risiko pekerjaan yang tinggi (X3) dengan loading faktor sebesar 0,698. Berdasarkan besarnya loading factor variabel tersebut diatas, ternyata variabel suka dengan pekerjaan (X2) memiliki pengaruh yang dominan di dalam faktor tuntutan tugas (faktor 2) sedangkan variabel risiko pekerjaan yang tinggi (X3) memiliki pengaruh yang paling kecil di dalam faktor tuntutan tugas (faktor 2). Faktor tuntutan fisik memiliki eigenvalue sebesar 1,747 dan dengan nilai persentase variance yang mempengaruhi stres kerja pada tenaga kebersihan kota di Dinas Lingkungan Hidup Kabupaten Gianyar Tahun 2017 sebesar 9,704\%. Faktor ini dibentuk oleh variabel-variabel sebagai berikut.Ruangan kantor yang sempit(X10) dengan loading factor sebesar 0,889 , kondisi cuaca yang berubah-ubah (X8) dengan loading factor sebesar 0,867 , udara yang tidak sehat ditempat kerja (X7) dengan loading factor sebesar 0,843 dan tidak nyaman dengan penataan ruang kantor (X9) dengan loading factor sebesar 0,819. Berdasarkan besarnya loading factor variabel variabel tersebut diatas, ternyata variabel Ruang kantor yang sempit (X10) memiliki pengaruh yang dominan di dalam faktor tuntutan fisik (faktor 3) sedangkan variabel tidak nyaman dengan penataan ruang kantor (X9) memiliki pengaruh yang paling kecil di dalam faktor tuntutan fisik (faktor 3). Faktor tuntutan antar personal memiliki eigenvalue sebesar 1,114 dan dengan nilai persentase variance yang mempengaruhi stres kerja pada tenaga kebersihan kota di Dinas Lingkungan Hidup Kabupaten Gianyar Tahun 2017 sebesar $6,191 \%$. Faktor ini dibentuk oleh variabel-variabel sebagai berikut.Tidak adanya kejelasan peran (X11) dengan loading factor sebesar 0,761 , dan tidak ada pembagian kerja yang jelas (X12) dengan loading factor sebesar 0,738. Berdasarkan besarnya loading factor variabel tersebut diatas, ternyata variabel tidak ada kejelasan peran (X11) memiliki pengaruh yang dominan di dalam faktor tuntutan peran (faktor 4) dan variabel tidak ada pembagian kerja yang jelas (X12) memiliki pengaruh terendah di dalam faktor tuntutan peran (faktor 4)

Dari penjelasan di atas maka faktorfaktor yang mempengaruhi stress kerja pada tenaga kebersihan kota di Dinas Lingkungan Hidup Kabupaten Gianyar Tahun 2017 adalah faktor tuntutan antar personal, faktor tuntutan tugas, faktor tuntutan fisik dan faktor tuntutan peran.

Tahap ke lima uji ketepatan model. Langkah ini merupakan langkah yang terakhir dari analisis faktor. Ketepatan model dapat diketahui dari besarnya residual yang terjadi. Residual adalah perbedaan korelasi yang diamati dan yang diproduksi berdasarkan estimasi matrik faktor. Pada penelitian ini besarnya persentase residual yang ditunjukkan adalah sebesar $15 \%$ atau sebanyak 24 residual atas dasar nilai absolut $>0,05$. $\mathrm{Hal}$ ini mengindikasikan bahwa model memiliki ketepatan model sebesar $85 \%$ pada tingkat kesalahan sebesar $5 \%$ atau dengan kata lain model dapat diterima dengan ketepatan $85 \%$. Berdasarkan hasil pengujian analisis faktor diatas, maka didapatkan hasil bahwa faktor yang dominan mempengaruhi stress kerja pada tenaga kebersihan kota di Dinas Lingkungan Hidup Kabupaten Gianyar Tahun 2017 adalah faktor tuntutan antar personal dengan nilai eigenvalue sebesar 6,492 serta nilai persentase variance sebesar $36,064 \%$. Khusus nya pada butir pertanyaan X16 yaitu mengenai kurangnya dukungan pimpinan dengan nilai loading factor sebesar 0,987. 


\section{Pembahasan}

Dari hasil penelitian yang telah didapatkan menunjukkan bahwa stress kerja pada tenaga kebersihan kota di Dinas Lingkungan Hidup Kabupaten Gianyar Tahun 2017 di pengaruhi oleh 4 faktor yaitu faktor (1) tuntutan antarpersonal, (2) tuntutan tugas, (3) tuntutan fisik dan (4) tuntutan peran. Hal ini bisa dilihat pada tabel 4.3 yang menunjukan nilai eigenvalue setiap faktornya. Kemudian faktor yang paling dominan mempengaruhi stress kerja adalah faktor tuntutan antar personal dengan nilai eigenvalue terbesar yaitu 6,492 dengan nilai persentase variance sebesar 36,064 \%. Khususnya pada butir soal X16 yaitu mengenai kurangnya dukungan pimpinan dengan nilai loading factor sebesar 0,987. Secara teori menurut Gregory Moonhead dan Ricky W. Griffin (2013) ada 4 faktor yang mempengaruhi stress kerja pada karyawan di dalam organisasi yaitu tuntutan tugas, tuntutan fisik, tuntutan peran dan tuntutan antarpersonal.

Tuntutan tugas merupakan stressor yang berkaitan dengan tugas spesifik yang dilakukan oleh seseorang. Dalam faktor ini stress dapat timbul dari jenis pekerjaan yang di geluti, keamanan dari pekerjaan itu sendiri dan kelebihan beban dari pekerjaan yang dilaksanakan.

Selanjutnya adalah tuntutan fisik yang berkaitan dengan fungsi dari karakteristik fisik dari situasi dan tugas fisik yang dibutuhkan dalam pekerjaan. Dimana dalam faktor ini stress dapat timbul dari temperatur dan desain kantor di tempat seseorang itu bekerja.

Kemudian faktor yang ketiga yaitu tuntutan peran yang merupakan stressor yang berkaitan dengan peran seseorang di dalam sebuah organisasi. Dalam faktor ini ambiguitas dalam pekerjaan menurut Gregory Moonhead dan Ricky W. Griffin (2013) dapat menimbulkan stress bagi karyawan dalam bekerja.

Dan faktor yang terakhir mempengaruhi stress dalam organisasi menurut Gregory Moonhead dan Ricky W. Griffin (2013) adalah tuntutan antar personal. Dalam faktor ini stress dapat timbul dari 3 hal yaitu tekanan kelompok, kepemimpinan, serta konflik antarpersonal.

Dari hasil penelitian ini, menunjukan adanya kesesuaian uji empirik dengan teori yang ada. Dimana stress kerja pada tenaga kebersihan kota di Dinas Lingkungan Hidup Kabupaten Gianyar Tahun 2017 dipengaruhi oleh 4 faktor yaitu faktor tuntutan antarpersonal, tuntutan tugas, tuntutan fisik dan tuntutan peran sesuai dengan teori yang dikemukakan oleh Gregory Moonhead dan Ricky W. Griffin (2013). Faktor yang paling dominan mempengaruhi stress kerja pada tenaga kebersihan kota di Dinas Lingkungan Hidup Kabupaten Gianyar Tahun 2017 adalah faktor tuntutan antar personal. Khususnya pada poin rendahnya dukungan dari pimpinan. Secara teori menurut Gregory Moonhead dan Ricky W. Griffin (2013) di dalam tuntutan antarpersonal terdapat poin mengenai kepemimpinan dimana rendahnya dukungan dari pimpinan akibat dari gaya kepemimpinan yang otokratis. Gaya kepemimpinan otokratis adalah gaya kepemimpinan yang tidak melibatkan karyawan dalam pengambilan keputusan di dalam organisasi.

Melihat pada gaya kepemimpinan yang di gunakan oleh pimpinan di Dinas Lingkungan Hidup Kabupaten Gianyar, dari beberapa tenaga kebersihan kota yang peneliti wawancarai bahwa pimpinan jarang melakukan penerjunan langsung ke lapangan untuk melihat dan memantau langsung tenaga kebersihan dalam bekerja maupun bercengkrama dengan tenaga kebersihan kota. Hal ini menciptakan sebuah jarak antara pimpinan dengan tenaga kebersihan kota sehingga aspirasi dari tenaga kebersihan kota dalam keluh kesal nya menjalani pekerjaan tidak dapat tersampaikan kepada pimpinan secara langsung. Hal ini mengakibatkan pimpinan kurang mendukung tenaga kebersihan kota sehingga terkesan menjalankan gaya kepemimpinan otokratis karena dalam pengambilan sebuah keputusan tidak melibatkan langsung tenaga kebersihan kota. Maka hal inilah yang dominan memicu timbulnya stress kerja pada tenaga kebersihan kota. 
Adapun dampak yang akan ditimbulkan akibat dari stress kerja di dalam organisasi menurut Gregory Moonhead dan Ricky W. Griffin (2013) adalah akan terjadinya penurunan dalam kinerja. Bagi pekerja, penurunan seperti ini dapat diterjemahkan menjadi kualitas kerja yang buruk yang berimbas pada penurunan produktivitas. Kemudian dampak kedua yaitu penarikan diri dimana bentuk penarikan diri yang dapat terjadi adalah absensi dan berhenti dari pekerjaannya. Selanjutnya dampak yang dapat diakibatkan dari stress kerja untuk organisasi nya adalah berhubungan dengan sikap. Perubahan sikap akibat stress ini dapat menyebabkan karyawan akan mudah mengeluh dalam bekerja. Dan yang terakhir adalah kelelahan. Kelelahan akibat stress kerja yang tinggi akan menghambat produktivitas dari organisasi tersebut dan hal ini tentu akan merugikan organisasi tersebut.

Melihat dampak yang diakibatkan oleh stress kerja di dalam organisasi, maka sebaiknya pemimpin harus terjun langsung ke lapangan untuk memantau sekaligus bercengkrama dengan tenaga kebersihan kota. Melihat dari hasil penelitian yang dilakukan bahwa faktor yang paling dominan mempengaruhi stress kerja pada tenaga kebersihan kota adalah tuntutan antarpersonal khususnya mengenai poin kurangnya dukungan dari pimpinan. Dengan pemimpin terjun langsung untuk memantau tenaga kebersihan kota maka tidak ada jarak antara pimpinan maupun tenaga kebersihan kota itu sendiri sehingga tenaga kebersihan kota dalam menyampaikan aspirasi serta keluh kesal dalam pekerjaannya akan langsung dapat didengar oleh pimpinan dan digunakan sebagai bahan pertimbangan dalam pengambilan keputusan.

\section{SIMPULAN DAN SARAN Simpulan}

Berdasarkan hasil penelitian dan pembahasan di atas, maka faktor-faktor yang mempengaruhi stress kerja pada tenaga kebersihan kota di Dinas Lingkungan Hidup Kabupaten Gianyar Tahun 2017 adalah tuntutan antar personal, tuntutan tugas, tuntutan fisik, dan tuntutan peran dan faktor yang paling dominan mempengaruhi stres kerja pada tenaga kebersihan kota di Dinas Lingkungan Hidup Kabupaten Gianyar Tahun 2017 adalah tuntutan antar personal dengan nilai eigenvalue tertinggi sebesar 6,492 serta nilai presentase variance tertinggi sebesar 36,064\%. Khususnya pada poin mengenai rendahnya dukungan pimpinan dengan nilai loading factor tertinggi di dalam faktor tuntutan antar personal sebesar 0,987.

\section{Saran}

Berdasarkan kesimpulan diatas, maka peneliti dapat memberikan beberapa saran sebagai berikut.Sebaiknya perlu adanya dukungan langsung dari pimpinan terhadap tenaga kebersihan kota dengan cara terjun langsung ke lapangan untuk bercengkrama sekaligus memantau langsung situasi kerja di lapangan. Dengan hal ini maka tidak ada jarak antara pemimpin maupun tenaga kebersihan kota sehingga tenaga kebersihan kota akan merasakan langsung dukungan dari pimpinannya. Maka tingkat stress kerja di dalam tenaga kebersihan kota akan dapat dikurangi sehingga kinerja dari tenaga kebersihan kota akan semakin maksimal diikuti dengan produktivitas dari Dinas Lingkungan Hidup Kabupaten Gianyar dalam menangani sampah akan semakin baik lagi di tahun-tahun berikutnya.

\section{DAFTAR PUSTAKA}

Brantas. 2009. Dasar-Dasar Manajemen. Bandung : CV Alfabeta.

Caputo, Janette S. 1991. Stress and Burnout in Library Service. Phoenix : Oryx Press.

Fahmi, Irham. 2013. Perilaku Organisasi : Teori, Aplikasi, dan Kasus, Bandung : CV Alfabeta.

Hasibuan, Malayu. 2012. Manajemen Sumber Daya Manusia. Jakarta: Bumi Aksara.

Moorhead Gregory dan Grriffin W.Ricky. 2013. Perilaku Organisasi: Manajemen Sumber Daya Manusia 
dan Organisasi. Jakarta Selatan : Salemba Empat.

Mulyadi Deddy dan Supiyadi Dedi. 2015. Perilaku Organisasi dan Kepemimpinan Pelayanan Bandung : CV Alfabeta.

Pines, A \& $E$ Aronson. 1989. Career Burnout : Causes and Cures. New York: A Divition of Micmillan.Inc.

Riduwan, Rusyana Adun dan Enas. 2013. Cara Mudah Belajar SPSS dan Aplikasi Statistik Penelitian. Bandung : CV Alfabeta

Saam Zulfan dan Wahyuni Sri. 2013. Psikologi Keperawatan. Jakarta : PT RajaGrafindo Persada.

Sunyoto Danang dan Burhanudin. 2015. Teori Perilaku Keorganisasian.Yogyakarta CAPS (Centre of Academic Publishing Service).

Sugiyono. 2007. Statistika untuk Penelitian. Bandung : alfabeta.

Sulistiyani Teguh dan Rosidah. 2003. Manajemen Sumber Daya Manusia : Konsep, Teori, dan Pengembangan dalam Konteks Organisasi Publik. Yogyakarta : Graha Ilmu.

Waluyo Minto. 2013. Manajemen Psikologi Industri. Jakarta Barat: PT Indeks. 